\title{
PENGEMBANGAN BAHAN AJAR DENGAN MENGGUNAKAN METODE SQ4R UNTUK MENINGKATKAN KEMAMPUAN MENGAJUKAN MASALAH MATEMATIS SISWA SMA
}

\author{
Luvy Sylviana Zanthy \\ IKIP Siliwangi \\ lszanthy@gmail.com
}

\begin{abstract}
ABSTRAK
Penelitian ini didasarkan pada permasalahan masih rendahnya kemampuan mengajukan masalah matematis siswa dan penggunaan bahan ajar siswa yang masih terbatas saat proses pembelajaran. Sebagai alternatif dari permasalahan tersebut dilakukan penelitian dengan mengembangkan bahan ajar Siswa dengan menggunakan metode SQ4R dalam pembelajaran. Penelitian ini merupakan bagian dari Penelitian Disertasi Doktor yang bertujuan untuk mengetahui kevalidan, kepraktisan dan keefektifan bahan ajar berupa LKS matematika dalam meningkatkan kemampuan mengajukan masalah matematis siswa. Jenis penelitian ini merupakan penelitian pengembangan (research and development) dengan menggunakan model ADDIE (Analysis, Design, Development, Implementation dan Evaluation). Subjek sampel dalam penelitian ini terdiri dari: 30 orang siswa kelas XII sebagai subjek kelas ujicoba dan 80 siswa kelas XI sebagai subjek kelas implementasi. Jenis data yang diambil dalam penelitian ini adalah data kualitatif dan kuantitatif. Teknik pengumpulan data berupa angket uji validitas, angket respon siswa dan instrumen tes kemampuan mengajukan masalah matematika. Sedangkan teknik analisis data dalam penelitian ini menggunakan analisis deskriptif, kualitatif dan inferensial. LKS hasil pengembangan dalam penelitian ini telah teruji dengan rata-rata kevalidan 3,44, rata-rata kepraktisan sebesar 3,89 dan nilai rata-rata tes kemampuan mengajukan masalah matematis siswa berada pada kriteria tinggi. Berdasarkan hasil tersebut maka dapat diidentifikasikan bahwa LKS yang menggunakan metode SQ4R ini valid, efektif dan praktis dalam meningkatkan kemampuan mengajukan masalah matematis siswa.
\end{abstract}

Kata Kunci: bahan ajar, model ADDIE, metode SQ4R, kemampuan mengajukan masalah matematis.

\begin{abstract}
This research is based on the student's of mathematical problem posing ability is still low and the use of student teaching materials that are still limited during the learning process. As an alternative to these problems, research is carried out by developing student teaching materials using the SQ4R method in learning. This research is part of the Doctoral Dissertation Research which aims to determine the validity, practicality and effectiveness of teaching materials in the form of mathematical LKS in improving the mathematical problem posing ability. This type of research is research and development using the ADDIE model (Analysis, Design, Development, Implementation, and Evaluation). The sample subjects in this study consisted of: 30 students of class XII as subjects of the experimental class and 80 students of class XI as subjects of the implementation class. The types of data taken in this study are qualitative and quantitative data. Data collection techniques in the form of validity test questionnaires, student response questionnaires and mathematical problem posing ability test. While the data analysis techniques in this study used descriptive, qualitative and inferential analysis. The LKS of the results of the development in this study have been tested with a validity average of 3.44, the average practicality of 3.89 and the average value of the mathematical problem posing ability test are of high criteria.
\end{abstract}


Based on these results, it can be identified that the LKS using the SQ4R method is valid, effective and practical in increasing students' mathematical problem posing ability.

Keywords: teaching materials, ADDIE models, SQ4R method, mathematical problem posing ability.

\section{PENDAHULUAN}

Dalam kegiatan menyelesaikan masalah matematika, seorang siswa akan dihadapkan dengan dua aspek penting, yaitu: masalah apa yang mungkin muncul atau diajukan dari sejumlah fakta atau informasi yang diperoleh (aspek mengajukan masalah) dan bagaimana menyelesaikan masalah tersebut (aspek memecahkan masalah). Dalam kegiatan yang bersifat mengajukan masalah matematis, seorang siswa memperoleh kesempatan untuk mengembangkan kemampuan matematisnya, mengidentifikasi faktafakta atau informasi yang diberikan serta permasalahan yang bisa muncul dari fakta-fakta atau informasi tersebut, sedangkan melalui kegiatan memecahkan masalah, seorang siswa dapat mengembangkan kemampuan berpikirnya untuk menyelesaikan masalah matematika yang tidak rutin.

Berbagai penelitian mengungkapkan bahwa dalam menentukan keberhasilan siswa, kemampuan siswa dalam mengajukan masalah tidak kalah penting dengan kemampuan memecahkan masalah. (Silver \& Cai, 1996) mengungkapkan bahwa kemampuan mengajukan masalah saling berdampak positif dengan kemampuan memecahkan masalah. Dalam referensi lainnya, (English, 1998) mengemukakan tentang manfaat kemampuan mengajukan masalah, diantaranya: (a) membantu mengembangkan sikap optimisme dan rasa senang dalam mempelajari matematika, (b) membantu siswa menumbuhkan sikap kritis dan kreatif; (c) memunculkan pengaruh positif terhadap kemampuan memecahkan masalah dan sikap positif siswa terhadap matematika; (d) menumbuhkan semangat dalam menemukan ide baru dan kemampuan berpikir siswa; (e) mendorong siswa untuk dapat lebih bertanggung jawab dalam belajarnya; (f) membantu siswa untuk mengetahui kesalahan yang dilakukan pada saat mempelajari matematika; (g) meningkatkan kemampuan pemecahan masalah, dan (h) menghilangkan rasa takut dan cemas dalam mempelajari matematika.

Pentingnya kemampuan mengajukan masalah dalam kurikulum matematika di semua jenjang sekolah sudah mulai diperhatikan. Dalam kurikulum 2013, mengajukan masalah (Menanya) termasuk dalam kemampuan yang harus dimiliki siswa dalam memecahkan masalah matematis (Kemendikbud, 2013). Pada dasarnya kemampuan 
mengajukan masalah berkaitan dengan kemampuan pemecahan masalah. Dalam pemecahan masalah siswa dilatih untuk memahami soal dengan baik, mengetahui apa yang diketahui dan ditanyakan. Selanjutnya siswa dibimbing untuk membuat model matematika dari soal yang diberikan dan menyelesaikannya. Setelah itu siswa dilatih untuk mengoreksi kembali keterkaitan jawaban dengan apa yang ditanyakan dalam soal, sehingga siswa dapat terlatih untuk menuliskan jawaban akhir yang sesuai dengan permintaan soal. Hal ini sejalan dengan (Kar, Özdemir, Ipek, \& Albayrak, 2010) bahwa kemampuan mengajukan masalah dan kemampuan memecahkan masalah saling berhubungan dan tidak dapat dipisahkan.

Beberapa pemaparan tentang pentingnya kemampuan mengajukan masalah matematika seperti yang telah diutarakan sebelumnya, sayangnya tidak diimbangi oleh kenyataan di lapangan. Berdasarkan penelitian yang dilakukan oleh (Putra, Herman, \& Sumarmo, 2017), menemukan bahwa kemampuan mengajukan masalah matematis siswa SMA masih kurang. Siswa yang diberi tugas menyelesaikan masalah matematika, sebagian siswa mengikuti dengan baik setiap penjelasan atau informasi dari guru dan masih sedikit siswa yang berani mengajukan masalah atau pertanyaan kepada guru. Selain itu, berdasarkan hasil observasi dan wawancara siswa yang dilakukan oleh (Sylviana Zanthy \& Yuspriyati, 2017) di salah satu sekolah menengah di Kota Cimahi, ditemukan bahwa buku teks matematika yang digunakan oleh guru masih sulit dipahami oleh siswa. Deskripsi materi masih terlalu pendek dan tidak adanya metode pembelajaran membuat siswa bingung dalam memecahkan masalah matematika.

Masih rendahnya kemampuan mengajukan masalah matematis juga berdampak pada hasil studi TIMSS 2015 (Mullis, Martin, Foy, \& Arora, 2015) dan PISA 2015 (OECD, 2018) yang memberikan gambaran bahwa walaupun capaian siswa Indonesia cukup signifikan dibanding tahun sebelumnya, namun secara umum masih dibawah rerata negara OECD (Organization for Economic Co-operation and Development). Siswa masih belum terbiasa menjawab soal-soal berstandar internasional terutama pada kemampuan berpikir tingkat tinggi.

Berbagai macam contoh permasalahan yang dikemukakan di atas tentu disebabkan oleh beberapa hal, diantaranya: Pertama, belum optimalnya peranan buku teks atau paket sebagai perangkat pembelajaran. Kedua, kemampuan matematis siswa yang masih rendah, dan ketiga, penggunaan metode pembelajaran yang kurang tepat.

Untuk dapat meningkatkan kemampuan mengajukan masalah, maka diperlukan bahan ajar yang menggunakan metode pembelajaran yang memungkinkan karakteristik 
$\overline{\text { dari kemampuan mengajukan masalah muncul. Peranan guru dengan menggunakan bahan }}$ ajar yang tepat akan menentukan tercapainya kompetensi dasar, tujuan pembelajaran, hasil belajar dan meningkatkan kemampuan mengajukan masalah siswa. Penggunaaan bahan ajar berbentuk LKS yang menggunakan metode SQ4R melalui model ADDIE diharapkan sebagai salah satu solusi untuk mengatasi permasalahan tersebut. Model ADDIE (Analysis, Design, Development, Implementation dan Evaluation) yaitu salah satu model desain pembelajaran yang tepat untuk menghasilkan suatu perangkat pembelajaran yang efektif, dinamis dan efesien. Adapun langkah-langkah model ADDIE dalam penelitian ini telah dimodifikasi berdasarkan tahapan pengembangan model Dick \& Carey (Ed Forest, 2015) berikut.

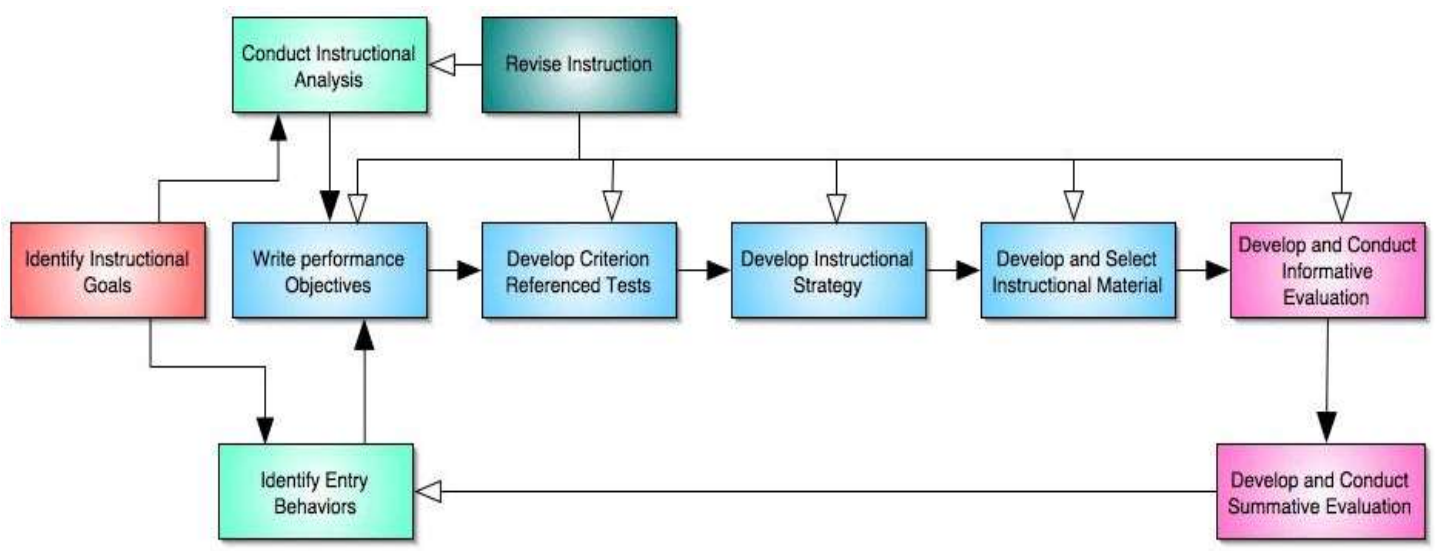

Dick and Carey Instructional Design Model

Gambar 1. Desain Model Dick \& Carey

Metode pembelajaran SQ4R adalah salah satu pembelajaran yang memuat langkahlangkah sesuai dengan karakteristik kemampuan mengajukan masalah. SQ4R merupakan modifikasi dari teknik membaca sebelumnya yang cukup terkenal yaitu model pembelajaran SQ3R dalam buku yang berjudul "Effective Study" pada pertengahan tahun 1940 karya Francis Robinson (Slavin, 2005). Perbedaan SQ4R dan SQ3R pada penelitian ini yaitu dengan menambahkan langkah Record pada langkah setelah Recite. Langkahlangkah SQ4R yaitu: survey, question, read, recite, record dan review.

Pada langkah survey, siswa mendapat suatu teks matematika atau tugas matematika dalam aspek kognitif tertentu. Langkah question, tugas siswa adalah menyusun pertanyaan atau masalah yang mengarahkan pada penyelesaian masalah matematika, langkah ini sesuai dengan indikator kemampuan mengajukan masalah, yaitu: memformulasi masalah dari serangkaian informasi dan mengajukan masalah yang dikaitkan dengan pemecahan masalah yaitu menyusun masalah sebelum, selama, dan sesudah penyelesaian masalah. 
Langkah read, siswa ditugaskan untuk membaca kembali teks atau soal untuk menjawab pertanyaan yang telah disusun. Pada langkah ini sesuai dengan indikator dari kemampuan mengajukan masalah yaitu mereformasi masalah atau mengkreasi masalah baru. Selanjutnya langkah recite, siswa menjawab pertanyaan atau masalah yang telah disusun, ini sesuai dengan indikator kemampuan mengajukan masalah yaitu: merinci masalah utama ke dalam masalah bagiannya.

Langkah record, siswa membuat catatan informasi penting untuk membantu siswa mengingat teks matematika atau tugas matematika yang diberikan tanpa membaca kembali informasi sebelumnya. Pada langkah terakhir, yaitu review, siswa memeriksa kembali jawaban untuk meyakinkan kebenaran jawaban..

Berdasarkan uraian di atas, penelitian ini bertujuan untuk: (a) memperoleh gambaran kualitas bahan ajar matematika untuk siswa SMA yang valid, praktis dan efektif dengan menggunakan metode pembelajaran SQ4R dalam meningkatkan kemampuan mengajukan masalah matematis siswa; (b) Mengkaji kesulitan atau kendala yang dihadapi siswa dalam melaksanakan tugas matematika yaitu mengajukan pertanyaan yang terkandung dalam bahan ajar, dan (c) Mengkaji kegiatan siswa dan pendapat siswa selama belajar menggunakan bahan ajar.

\section{METODE PENELITIAN}

Desain penelitian yang digunakan dalam penelitian ini adalah desain pengembangan bahan ajar (Research and Development). Bahan ajar yang dikembangkan adalah Lembar Kegiatan Siswa (LKS) materi polinomial yang menggunakan metode pembelajaran SQ4R, yaitu: Survey, Question, Read, Recite, Record dan Review.

Subyek dalam penelitian ini adalah 30 orang siswa kelas XII sebagai subjek kelas ujicoba dan 80 siswa kelas XI sebagai subjek kelas implementasi yang terdiri dari satu kelas sebanyak 40 orang siswa kelas XI yang menggunakan metode pembelajaran SQ4R dan satu kelas sebanyak 40 orang siswa kelas XI yang menggunakan pembelajaran biasa di salah satu SMA Negeri di Cimahi. Instrumen yang digunakan dalam penelitian ini meliputi: a) lembar validasi silabus, RPP dan lembar validasi LKS; b) lembar observasi, c) Angket respon siswa terhadap pembelajaran, dan c) Instrumen tes kemampuan mengajukan masalah matematis siswa.

Penelitian ini merupakan bagian dari penelitian disertasi dengan skim hibah disertasi doktor. Tahap-tahap yang dilakukan dalam penelitian ini meliputi 3 fase, yaitu: 
studi pendahuluan, tahap pengembangan bahan ajar dan tahap akhir. Untuk lebih jelasnya, dapat dilihat pada Gambar berikut.

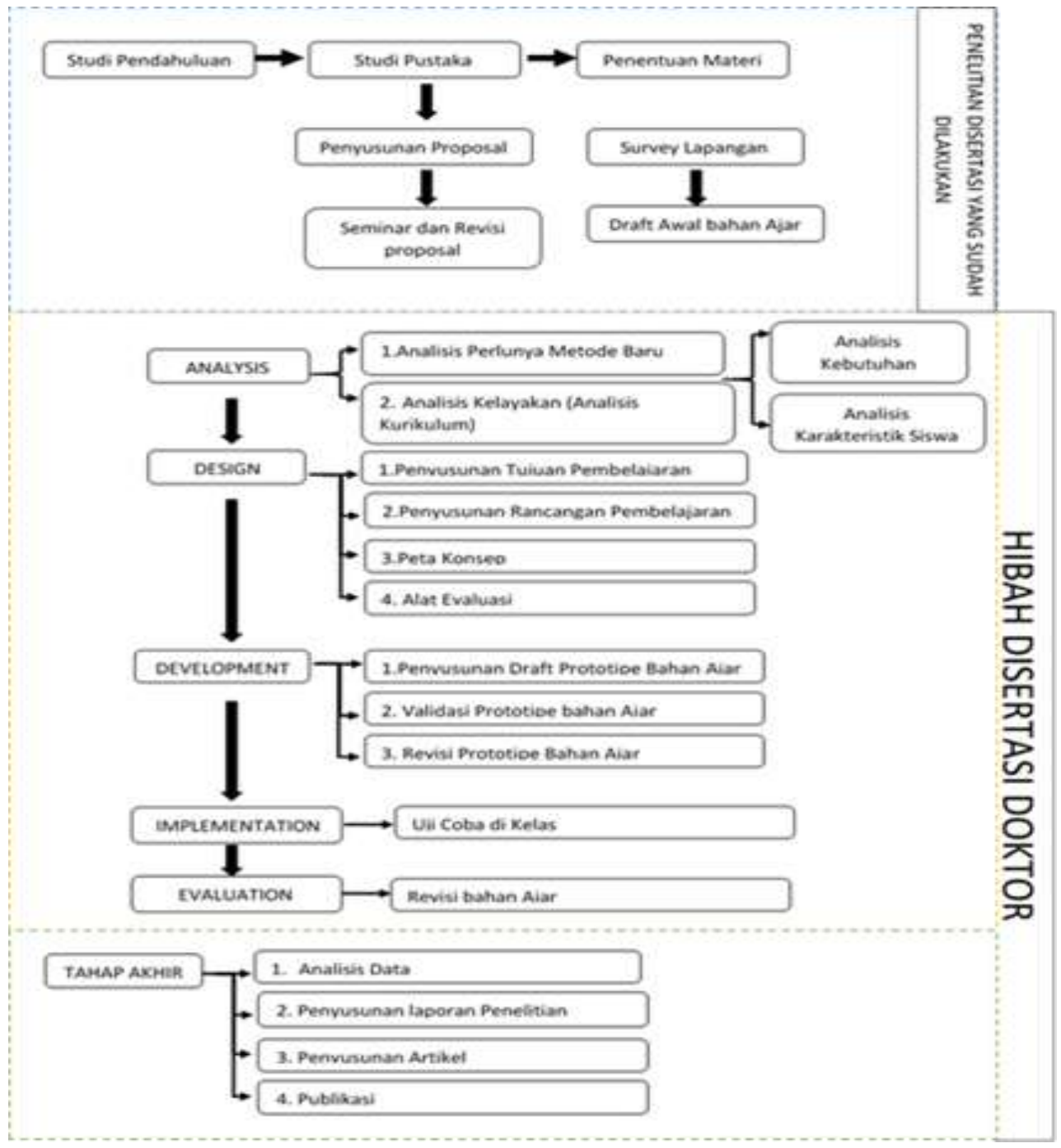

Gambar 2. Diagram Alur Penelitian

\section{Studi Pendahuluan}

Studi pendahuluan yang mendasari penelitian ini dilakukan dengan menelaah sejumlah literatur yang membahas tentang kemampuan mengajukan masalah, metode SQ4R dan bahan ajar. Pada tahap ini dihasilkan definisi operasional variabel penelitian dan indikator-indikatornya sebagai berikut: Kemampuan mengajukan masalah matematis adalah kemampuan siswa membentuk masalah dan meformulasikan masalah matematika berdasarkan data atau informasi matematika yang diberikan dengan beragam cara dalam rangka mencari alternatif pemecahan masalah matematika. Sedangkan Indikatornya adalah: 1) Mengajukan atau menyusun pertanyaan atau masalah dari serangkaian informasi matematika yang semi terstruktur berkenaan konten atau kemampuan matematis atau tingkat kelas subyek tertentu; 2) Menyatakan suatu pertanyaan atau masalah matematika ke 
dalam bentuk lain yang baru dengan makna yang sama; 3) Merinci masalah utama dari suatu soal matematika yang tidak sederhana ke dalam masalah-masalah bagiannya, dan 4) Menyusun atau mengajukan masalah sebelum, selama, dan sesudah pemecahan masalah.

Selain definisi operasional dan indikatormya, ditemukan juga beberapa hasil penelitian relevan, diantaranya adalah: (1) Penelitian dari (Sylviana Zanthy \& Yuspriyati, 2017) tentang pengembangan bahan ajar melalui pendekatan saintifik untuk meningkatkan kemampuan berpikir kreatif matematis; (2) (Singer, Ellerton, \& Cai, 2013) yang mengemukakan tentang kemampuan mengajukan maslalah di pendidikan matematika, dan (3) Penelitian oleh (Ebih AR. Arhasy, 2015) tentang Pengaruh Penggunaan Pembelajaran Kontekstual dengan Teknik SQ4R terhadap Peningkatan Kemampuan Pemahaman dan Berpikir Kritis Matematis Siswa SMA.

\section{Tahap Pengembangan Bahan Ajar}

Jenis data yang dikumpulkan dalam tahap ini yaitu data kualitatif dan kuantitatif. Data kualitatif diperoleh berdasarkan hasil pengamatan, dokumentasi, serta validasi perangkat. Data kuantitatif diperoleh berdasarkan hasil tes kemampuan mengajukan masalah matematis. Sedangkan teknik analisis data yang digunakan adalah:

\section{Analisis data kevalidan Bahan Ajar}

Kevalidan bahan ajar yang dinilai validator diadaptasi dari Hobri (Pembelajaran et al., 2012) seperti pada Tabel berikut.

Tabel 1. Kriteria Kevalidan Bahan Ajar

\begin{tabular}{lr}
\hline Nilai Rata-rata Validator & Kriteria \\
\hline $1 \leq V_{A}<2$ & Tidak Valid \\
$2 \leq V_{A}<3$ & Kurang Valid \\
$3 \leq V_{A}<4$ & Cukup Valid \\
$4 \leq V_{A}<5$ & Valid \\
$V_{A}=5$ & Sangat Valid \\
\hline \multicolumn{2}{c}{ Keterangan: $V_{A}=$ Rata-rata penilaian validator }
\end{tabular}

\section{Analisis data kepraktisan Bahan Ajar}

Analisis data kepraktisan perangkat pembelajaran dilihat dari hasil penerapan bahan ajar di kelas. Teknik pengumpulan data dengan cara memberikan lembar observasi pelaksanaan pembelajaran kepada siswa, serta analisis data kemampuan guru mengelola pembelajaran. Bahan ajar dikatakan praktis jika hasil pengamatan terhadap penerapan bahan ajar terlaksana dengan minimal termasuk kriteria cukup baik. Kriteria kepraktisan bahan ajar dalam penelitian ini mengacu pada Hobri (Pembelajaran et al., 2012), yaitu:

Tabel 2. Kriteria Kepraktisan Bahan Ajar

\begin{tabular}{lr}
\hline Nilai Rata-rata Validator & Kriteria \\
\hline $\mathrm{KM}=5$ & Sangat Baik \\
\hline
\end{tabular}




\section{Analisis data keefektifan Bahan Ajar}

Analisis data keefektifan pembelajaran, meliputi uji normalitas, uji homogenitas, uji ketuntasan (proporsi), uji banding, uji beda proporsi, uji pengaruh, dan uji peningkatan.

\section{HASIL DAN PEMBAHASAN}

Pada kegiatan tahap pengembangan bahan ajar, dilakukan langkah-langkah model ADDIE yang dimodifikasi dari Dick \& Carey (Ed Forest, 2015).

\section{Analisis (Analysis)}

Dalam tahap ini terdapat dua kegiatan dilakukan, yaitu: a) analisis kebutuhan dan analisis karakteristik siswa.; b) analisis kurikulum dilakukan sebagai persyaratan untuk menyusun bahan ajar yang sesuai dengan kompetensi inti, kompetensi dasar dan indikator pencapaian. Pada kegiatan analisis kebutuhan dan karakteristik siswa, peneliti menganalisis kebutuhan prioritas yang segera perlu dipenuhi yang bertujuan untuk mengetahui adanya suatu keadaan yang seharusnya ada (what should be) dan keadaan nyata di lapangan (what is).

Dalam analisis kurikulum, peneliti mengidentifikasi kompetensi inti (KI) dan kompetensi dasar (KD) serta bahan ajar yang dikompilasi dalam bentuk bahan ajar Siswa (LKS) materi polinomial untuk pembelajaran matematika di kelas XI menggunakan metode SQ4R. Setelah dilakukan analisis pada tahap ini, ditemukan beberapa masalah seperti: guru masih merasa kesulitan dalam menyampaikan materi polinomial, siswa kurang aktif pada saat pembelajaran di kelas sehingga hal ini menyebabkan pembelajaran satu arah dimana guru lebih banyak memberikan informasi dan menjelaskan materi, sementara siswa hanya mencatat apa yang guru tulis di depan kelas, belum optimalnya peranan buku paket sebagai perangkat pembelajaran, kemampuan matematis siswa yang masih rendah, dan penggunaan metode pembelajaran yang kurang tepat. Berdasarkan masalah tersebut, maka dirasakan perlu untuk menyusun bahan ajar yang relevan dengan kebutuhan siswa, lingkungan belajar, teknologi dan karakteristik siswa menggunakan metode pembelajaran baru. 


\section{Desain (Design)}

Kegiatan yang dilakukan adalah menyusun tujuan pembelajaran, desain pembelajaran, peta konsep dan alat evaluasi yang sesuai dengan karakteristik metode SQ4R yang masih konseptual. Dalam analisis karakteristik siswa, ditemukan bahwa siswa kelas XI telah secara intelektual mulai berpikir logis tentang ide-ide abstrak. Wawasan pemikirannya telah menjadi lebih luas sehingga ia dapat menggunakan abstraksi dan membedakan yang konkret dan abstrak. Karakteristik siswa-siswa ini konsisten dengan karakteristik periode kognitif periode operasional Teori Piaget.

Menurut Teori Piaget (Lefa, 2014), saat ini, beberapa orang sudah memiliki kemampuan untuk berpikir abstrak, memberikan alasan secara logis, dan menarik kesimpulan dari informasi yang tersedia. Namun, tidak semua orang dapat mencapai kemampuan berpikir dan pengembangan pada tahap ini, sehingga masih ada kemungkinan bahwa masih ada siswa yang membutuhkan visualisasi konsep abstrak.

Pada tahap ini, peneliti merancang perangkat pembelajaran beserta instrumen yang dikembangkan. Perangkat pembelajaran yang dikembangkan adalah Silabus, RPP, LKS, dan tes kemampuan mengajukan masalah matematis yang disesuaikan dengan karakteristik metode pembelajaran SQ4R. Instrumen penelitian yang telah dirancang meliputi lembar validasi perangkat pembelajaran, lembar pengamatan keaktifan siswa dan kemampuan guru dalam mengelola pembelajaran serta lembar angket respon siswa terhadap pembelajaran. Setelah dilakukan revisi berdasarkan saran dan masukan dari tim validator, maka dihasilkan bahan ajar polinomial seperti pada Gambar berikut:

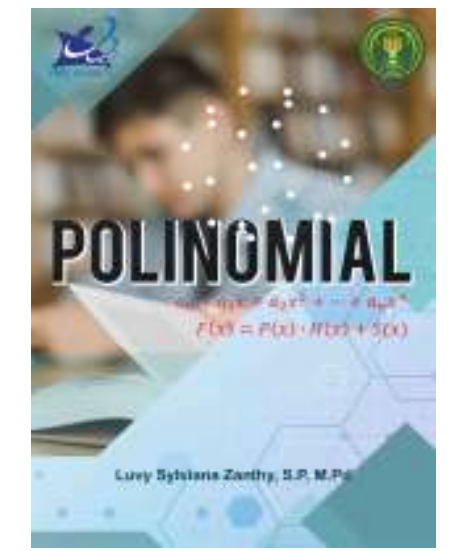

Gambar 3. Bahan Ajar Polinomial

Muslich (Firdaus, Suyanto, \& Samhati, 2014) berpendapat bahwa kelayakan isi suatu bahan ajar harus memperhatikan indikator sebagai berikut: 1) kesesuaian uraian materi dengan kompetensi inti dan kompetensi dasar yang terdapat pada kurikulum; 2) keakuratan materi, dan 3) materi pendukung pembelajaran. Sejalan dengan Muslich, 
$\overline{\text { (Arikunto, 2010) menuturkan bahwa materi atau bahan pelajaran merupakan unsur inti }}$ yang ada dalam kegiatan belajar mengajar, karena memang bahan ajar itulah yang diupayakan untuk dikuasai oleh siswa. Seorang guru harus memikirkan sejauh mana bahan-bahan atau topik yang tertera pada silabus berkaitan dengan kebutuhan siswa di masa depan.

\section{Pengembangan (Development)}

Pada tahap ini, disusun prototype perangkat pembelajaran. Tahap ini terdiri dari validasi perangkat pembelajaran dan ujicoba. Validasi dilakukan oleh Tim validator. Saran dan masukan dari tim validator digunakan untuk merevisi perangkat pembelajaran sehingga hasil perangkat pembelajaran itu dapat dikategorikan baik dan layak untuk diujicobakan di lapangan.

Secara umum penyajian bahan ajar berupa lembar kegiatan siswa ini diawali dengan petunjuk pengisian LKS, penyajian masalah matematika, tugas yang harus dilakukan siswa dan penyelesaian masalah matematika yang disusun per-langkah penyelesaian. Berdasarkan Gambar 4, maka dapat disimpulkan rata-rata hasil validasi Silabus, RPP dan LKS termasuk dalam kategori VALID. Setelah perangkat pembelajaran divalidasi dan dinyatakan layak diujicobakan, selanjutnya dilakukan uji coba perangkat pembelajaran pada kelas eksperimen. Uji coba perangkat pembelajaran di lapangan bertujuan untuk mencari kepraktisan dan keefektifan perangkat pembelajaran.

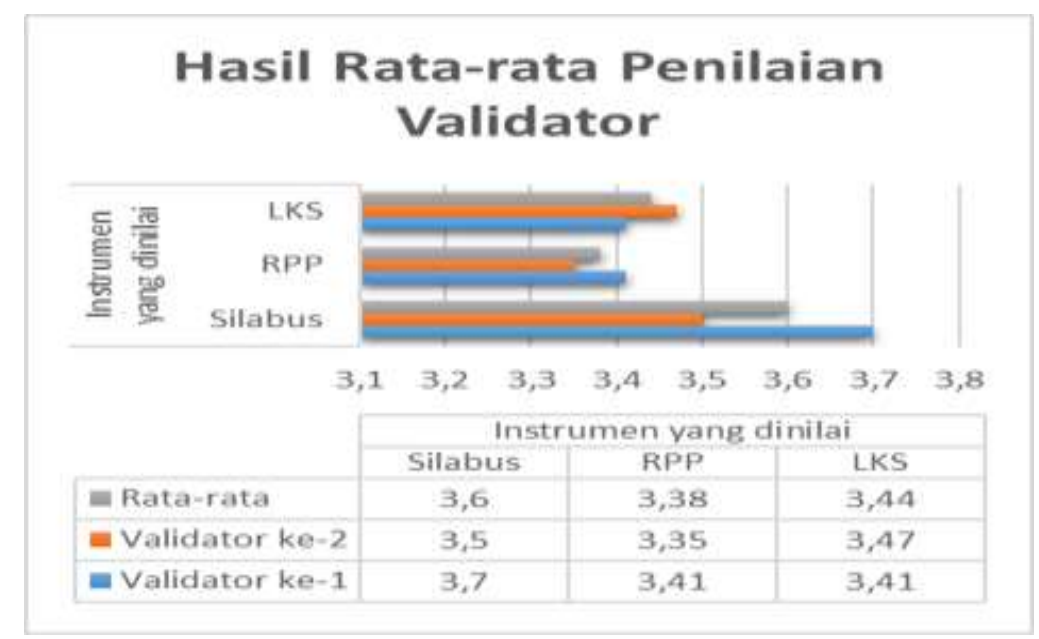

Gambar 4. Hasil Rata-rata Penilaian Validator terhadap Silabus, RPP dan LKS

Rekapitulasi analisis hasil uji coba butir soal tes kemampuan mengajukan masalah matematis disajikan dalam Tabel 3 . 


\begin{tabular}{|c|c|c|c|c|c|c|c|}
\hline No & $\begin{array}{c}\text { Nilai } \\
r_{x y}\end{array}$ & Kriteria & $\begin{array}{c}\text { Indeks } \\
\text { Tingkat } \\
\text { Kesukaran }\end{array}$ & Kriteria & $\begin{array}{c}\text { Indeks } \\
\text { Daya } \\
\text { Pembeda }\end{array}$ & Kriteria & $\begin{array}{c}\text { Nilai } \\
\text { Reliabilitas }\end{array}$ \\
\hline 1 & 0,64 & Valid & 0,89 & Mudah & 0,36 & Baik & \\
\hline 2 & 0,62 & Valid & 0,27 & Sulit & 0,24 & Cukup, soal perlu diperbaiki & 0,84 \\
\hline 3 & 0,64 & Valid & 0,75 & Mudah & 0,37 & Baik & (sangat \\
\hline 4 & 0,64 & Valid & 0,63 & Sedang & 0,28 & Cukup, soal perlu diperbaiki & tinggi) \\
\hline 5 & 0,63 & Valid & 0,67 & Sedang & 0,37 & Baik & \\
\hline
\end{tabular}

Berdasarkan hasil pada Tabel 3, maka semua soal termasuk dalam kriteria valid dan reliabel. Perangkat pembelajaran dikatakan praktis jika setelah diujicobakan pada kelas eksperimen memperoleh hasil: (1) respon siswa positif, dan (2) kemampuan guru dalam mengelola pembelajaran minimal baik. Data respon siswa kemudian dianalisis dengan menentukan banyaknya siswa memberi jawaban bernilai respon positif dan negatif untuk kategori yang ditanyakan dalam angket. Dari hasil pengisian angket respon siswa kemudian dipersentase dan diperoleh bahwa 78,15\% siswa memberikan respon positif, dengan kata lain siswa memberikan respon positif karena lebih dari $75 \%$ siswa memberikan respon positif terhadap pembelajaran menggunakan metode SQ4R.

\section{Implementasi (Implementation)}

Pembelajaran dikatakan efektif jika setelah dilakukan ujicoba, hasilnya sebagai berikut: a) kemampuan mengajukan masalah matematis siswa pada materi polinomial mencapai ketuntasan belajar individu dan klasikal; b) kemampuan mengajukan masalah matematis siswa kelas yang menggunakan metode pembelajaran SQ4R lebih tinggi dari pada kelas yang menggunakan pembelajaran biasa, dan c) adanya peningkatan kemampuan mengajukan masalah matematis siswa pada kelas yang menggunakan metode pembelajaran SQ4R. Setelah dilakukan uji statistik berupa nilai z, uji beda rata-rata, uji beda proporsi, dan uji gain, maka dapat disimpulkan bahwa kemampuan mengajukan masalah matematis pada siswa yang menggunakan metode pembelajaran SQ4R lebih baik dibandingkan kemampuan mengajukan masalah siswa yang menggunakan pembelajaran biasa dan rataan skor gain kelas yang menggunakan metode pembelajaran SQ4R lebih baik dari kelas yang menggunakan pembelajaran biasa.

\section{Evaluasi (Evaluation)}

Evaluasi dilakukan untuk mengetahui kendala dan kesulitan yang dihadapi siswa dalam melaksanakan tugas matematika yang terdapat dalam bahan ajar dan gambaran kegiatan siswa secara umum dalam menggunakan bahan ajar selama proses pembelajaran. Gambaran kinerja siswa secara umum dalam menjawab pertanyaan pada bahan ajar adalah: 
1) siswa kurang memperhatikan pertanyaan dalam soal sehingga jawaban siswa kurang lengkap; 2) siswa kesulitan pada saat menyusun atau mengajukan masalah sebelum, selama, dan sesudah pemecahan masalah. Kesulitan ini dialami dikarenakan siswa belum memahami konsep pada materi polinomial dan tidak terbiasa dengan jenis soal yang diberikan, sehingga siswa tidak mengerti langkah-langkah yang harus dilakukan pada saat diberikan soal pemecahan masalah; 3) siswa kurang hati-hati dalam menjawab soal, sehingga masih ada salah perhitungan, dan 4) siswa tidak memeriksa kembali pekerjaan yang sudah dilakukan.

Gambaran aktivitas siswa selama proses pembelajaran berlangsung adalah pada awal pembelajaran siswa nampak kebingungan. Aktivitas siswa dalam mengikuti pembelajaran baik dalam diskusi kelompok atau belajar mandiri kurang memperlihatkan kinerja yang memadai. Tetapi setelah beberapa kali pertemuan, siswa lebih aktif dan berani bertanya dan mengemukakan pendapatnya serta antusias dalam diskusi kelompok ataupun belajar mandiri.

Setelah dilakukan evaluasi terhadap bahan ajar berdasarkan temuan di atas dan masukan serta saran dari semua validator dan pembimbing, maka peneliti melakukan beberapa perbaikan pada bahan ajar sehingga diperoleh bahan ajar yang dikembangkan valid, praktis, dan efektif.

\section{KESIMPULAN}

Berdasarkan hasil dan temuan yang sudah diuraikan sebelumnya, maka dapat disimpulkan bahwa bahan ajar materi polinomial yang menggunakan metode pembelajaran SQ4R termasuk dalam kategori valid, praktis, dan efektif. Respon siswa terhadap pembelajaran menunjukkan respon positif dan hasil observasi guru terhadap pembelajaran termasuk dalam kriteria sangat baik.

\section{REKOMENDASI}

Penelitian ini memberikan beberapa rekomendasi berikut: Guru dapat menjadikan bahan ajar yang menggunakan metode pembelajaran SQ4R sebagai alternatif dalam melaksanakan proses pembelajaran matematika. Untuk dapat melaksanakan pembelajaran menggunakan metode SQ4R secara baik, guru perlu mengetahui konsepsi awal siswa sebelum pembelajaran agar dapat dijadikan dasar pembelajaran untuk mengatasi miskonsepsi siswa. Berbagai prediksi dan antisipasi yang telah dipersiapkan dalam skenario pembelajaran dengan baik, akan mempermudah guru melakukan tindakan yang 
tepat ketika siswa mengalami kesulitan dalam menyelesaikan masalah, sehingga akan memperlancar jalannya proses pembelajaran yang menggunakan metode SQ4R. Untuk peneliti selanjutnya, penelitian ini dapat dilanjutkan dengan menggunakan metode SQ4R terhadap kemampuan matematis dan materi lainnya.

\section{UCAPAN TERIMAKASIH}

Ucapan terima kasih disampaikan kepada Direktorat Riset dan Pengabdian Masyarakat, Direktorat Jenderal Penguatan Riset dan Pengembangan, Kementrian Riset, Teknologi dan Pendidikan Tinggi Republik Indonesia yang telah memberikan dana untuk penelitian ini melalui Penelitian Disertasi Doktor Tahun Anggaran 2018.

\section{REFERENSI}

Arikunto. (2010). Prosedur Penelitian Suatu Pendekatan Praktik. Rineka Cipta. https://doi.org/10.1016/j.minpro.2005.02.005

Ebih AR. Arhasy, R. R. dan Y. H. (2015). kontribusi pembelajaran kontekstual dengan teknik sq4r Terhadap peningkatan kemampuan pemahaman dan berpikir kritis matematis. Siliwangi.

Ed Forest. (2015). Dick and Carey Instructional Model. Frameworks and Theories. https://doi.org/10.4103/1995-705X.137489

English, L. D. (1998). Children's Problem Posing within Formal and Informal Contexts. Journal for Research in Mathematics Education. https://doi.org/10.2307/749719

Firdaus, A., Suyanto, E., \& Samhati, S. (2014). ANALISIS KELAYAKAN ISI BUKU TEKS BAHASA INDONESIA TERBITAN ERLANGGA KELAS VII SMP/MTs. Jurnal Kata.

Kar, T., Özdemir, E., Ipek, A. S., \& Albayrak, M. (2010). The relation between the problem posing and problem solving skills of prospective elementary mathematics teachers. In Procedia - Social and Behavioral Sciences. https://doi.org/10.1016/j.sbspro.2010.03.239

Kemendikbud. (2013). Peraturan Menteri Pendidikan dan Kebudayaan Republik Indonesia Nomor 65 Tahun 2013. Permendikbud No. 66 Tentang Standar Penilaian Pendidikan. https://doi.org/10.1017/CBO9781107415324.004

Lefa, B. (2014). THE PIAGET THEORY OF COGNITIVE DEVELOPMENT:AN EDUCATIONAL IMPLICATIONS. Educational Psychology.

Mullis, I. V. S., Martin, M. O., Foy, P., \& Arora, A. (2015). TIMSS 2015 International Results in Mathematics. TIMSS 2015 International Results in Mathematics. https://doi.org/10.1002/yd.20038

OECD. (2018). Pisa 2015 Results in Focus. OECD Publishing 2018. https://doi.org/10.1787/9789264266490-en

Pembelajaran, P. P., Materi, P., Redoks, K., Pilar, E., Melalui, P., \& Study, L. (2012). Empat Pilar Pendidikan Melalui Lesson Study.

Putra, H. D., Herman, T., \& Sumarmo, U. (2017). Development of Student Worksheets to Improve the Ability of Mathematical Problem Posing. International Journal on Emerging Mathematics Education. https://doi.org/10.12928/ijeme.v1i1.5507

Silver, E. A., \& Cai, J. (1996). An Analysis of Arithmetic Problem Posing by Middle 


School Students. Journal for Research in Mathematics Education.
https://doi.org/10.2307/749846

Singer, F. M., Ellerton, N., \& Cai, J. (2013). Problem-posing research in mathematics education: New questions and directions. Educational Studies in Mathematics. https://doi.org/10.1007/s10649-013-9478-2

Slavin, R. E. (2005). Cooperative Learning: Teori, Riset, dan Praktik. Nusa Media. Bandung. https://doi.org/10.1007/s11663-016-0878-4

Sylviana Zanthy, L., \& Yuspriyati, D. N. (2017). Development of materials through the scientific approach to improve mathematical creative thinking. 6 th World Conference on Applied Sciences, Engineering \& Technology. 